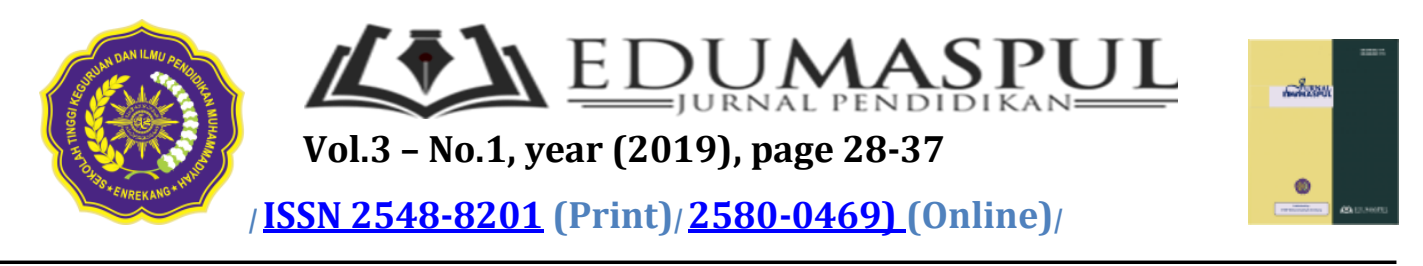

\title{
The Use of Prezi with KWL Strategy to Enhance Students Reading Comprehension
}

\author{
Musdalifah Ifah Rahman \\ English Education Department, STKIP Muhammadiyah Enrekang, Indonesia \\ Jalan Jenderal Sudirman No. 17 Enrekang, Sulawesi Selatan 91712, Indonesia \\ *Corresponding Author. E-mail: musdalifah25okt@gmail.com
}

\begin{tabular}{|l|l|l|}
\hline Receive: 12/01/2019 & Accepted: 22/03/2019 & Published: 02/04/2019
\end{tabular}

\begin{abstract}
The objectives of this research were to find out whether the use of Prezi with KWL Strategy enhances the reading comprehension and the students' interest. This research employed quasi experimental design. The population of this research was the first grade students of SMA 2 Enrekang in academic 2017/2018. This research employed cluster random sampling technique. The sample consisted of 72 students which belong to two classes; 36 students in experimental class and also 36 students in control class. Research instruments were used to collect the data in this research namely reading comprehension test and questionnaire. The result of the students' reading score in this research showed that the experimental class improved significantly from 69.69 up to 86.61. While, in control class the result improved from 66.22 up to 75.89. Therefore, the significant values of Independent $t$-test $0.000<\alpha=0.05$. It means that the alternative hypothesis $\left(H_{1}\right)$ was accepted. Moreover, based on the students' response on questionnaire showed that the mean score of interest was 80.61 and it was categorized as interested.
\end{abstract}

Key Words: KWL Strategy, Prezi, reading comprehension, interest

\section{INTRODUCTION}

Reading is eye working processes that information transfers into brain for produce the information (William, 2016, p.2730). In other explanation, reading comprehension as an exercise dominated by the eyes and the brain"
(Harmer, 2017, p.255). Furthermore, reading comprehension is essential skill that supports students in teaching and learning process, national examination, even in proficiencies test (TOEFL and IELTS) (Pintrich et.al, 2017, p.178). Finally, Zare, et.al (2017, p.40-45) comment that reading 
comprehension is a cognitive activity in which the reader takes part in a conversation with the author through the text. In conclude that, reading comprehension entails more than knowledge of vocabulary and syntax. It also requires ability to perceive the exact nature of being communicated (Rivers, 2016, p.74).

Some difficulties and problems faced by the teachers in their reading have appeared for long time. One of the problems namely: many students sometimes get bored and cannot continue reading the text in the textbook because the students are not able to answer the question and they did not comprehend the content of the text and they did not have many vocabularies to understand the text and were not interested in reading.

Dealing with the difficulty in reading comprehension, the first grade students of SMA 2 Enrekang shown by the low reading comprehension. It is still less than the standard of Minimum Completeness Criterion or Kriteria Ketuntasan Minimal (KKM) of English subject of SMA 2 Enrekang that is 76. In other words, the English score that the students gain is 70 at average. Thus, it still needs to be enhanced in order to reach 76 or higher than it.

Referring to obstacles above, the researcher implemented one interesting strategy and media in teaching reading comprehension, and strategy and media those are KWL strategy and Prezi media. This media and strategy can give positive impact (purpose) on students; interest in studying English as well as in improving reading comprehension.
One of the purposes of Prezi with KWL strategy that is enhances the reading comprehension and the students' interest in studying English reading. Interest is desire or curiosity to know deeply about something that reflects from attitude, attention, even perception (Good, 2016, p.78).

According to Riswanto (2017, p.35), Know, Want, Learned (KWL) strategy is effective to use improving students' reading comprehension showed that the effectiveness was indicated by result of the step wise regression formula that the contribution of KWL strategy on students' reading comprehension achievement was significantly improved. It is strategy can help students become good readers by getting them to do many of the things that good readers do and also this strategy gets students to read silently with comprehension (Ogle, 2018, p.35). In conclude that KWL strategy is strategies that creates students' to enhance reading comprehension in content areas (Jared et.al, 2017, p.90) and it is used to guide students through a text (Ogle, 2018, p.77-80). The students begin by brainstorming everything they Know about a topic. This information is recorded in the $K$ column of a KWL chart. Students then generate a list of questions about what they Want to Know about the topic. These questions are listed in the $W$ column of the chart. During or after reading, students answer the questions that are in the $W$ column. This new information that they have Learned is recorded in the $L$ column of the KWL chart.

In addition, Prezi is one of useful media in teaching and 
learning. It is software manufacturing slide presentations online. In contrast, Power Point, Prezi provides more free space to create idea in the manufacture of slide presentation. One of the advantages of Prezi is the zoomable canvas so that the presenter can focus slide into every sentence with the slide movement is quite dynamic and varied. Interesting learning media will make students more stimulated to pay attention to the material presented; therefore, the purpose of the material would be more easily understood. In other explanation, Prezi is a cloud-based presentation editor that allows the user to create presentation that zoom (Strasser, 2016, p.90-98).

\section{METHOD}

\section{Design and Samples}

This research applied quasi experimental design by using two groups namely; an experimental and a control group. The researcher used cluster random sampling technique which means two classes from the seven classes $\left(\mathrm{X}_{1}-\mathrm{X}_{7}\right) . \mathrm{X}_{2}$ was taken as experimental group and $\mathrm{X}_{4}$ was taken as control group. The result of calculation of the total number sample was 72 students. The experimental group employed treatment by using Prezi with KWL Strategy, while the control group was employed treatment by using three phase technique which both of these ways used narrative text. Both of groups were given pre-test and posttest.

\section{Instruments and Procedures}

This research used two kinds of instruments in collecting data namely reading test and questionnaire. In reading test, the students were given a narrative reading test means that the researcher provided multiple choices. It administered in pre-test and post-test. Pre-test was used to measure of the prior knowledge of the students, while post-test was aimed to see the students' reading comprehension after giving the treatment in experimental and control group for six meetings to enhance reading comprehension. Meanwhile, a questionnaire was distributed to students in the experimental group to measure their interest in learning reading process through Prezi with KWL strategy.

\section{a. Experimental Group}

There were some procedures of the treatment which were used for experimental group, and all of them were as follows:

1. The researcher explained about the procedure of using Prezi and explained about the texts (narrative text) that learn through KWL Strategy.

2. The researcher explained the objectives and the procedures of teaching and learning process for the students. It aimed to set a purpose for reading.

3. The researcher shown a text in Prezi Presentation and gave instruction.

4. One of the students in each group must be logged in their Prezi

5. After logging in, the students created KWL charts. 
6. Each group read the title and concern on the content of the text. It helped students to monitor their comprehension.

7. The researcher asked students to brainstorm words, terms, or phrases they associated with a topic and filled out the K column in their Prezi.

8. The researcher asked students what they wanted to learn about the topic and filled out on the W column in their Prezi.

9. The researcher had students to read the text and fill out the $\mathrm{L}$ column of their charts in their Prezi.

10. The students discussed the information that students recorded in the L column.

11. The researcher encouraged students to search any questions in the $\mathrm{W}$ column that were not answered by the text. It provided an opportunity for students to expand ideas beyond the text.

12. The researcher checked the Prezi Presentation from each group. It allowed students assessing their comprehension of the text.

\section{b. Control Group}

The process of the treatment in the control group was conducted in chronological order as follows:

1) The researcher explained the objectives of the teaching and learning process to the students.

2) The researcher introduced the topic of the reading text.

3) The researcher asked the students to read the text.

4) The researcher asked the students to find the difficult words and find their meaning by using dictionary.

5) The researcher asked the students to answer the questions of the text.

6) The researcher monitored the students' activities.

7) The researcher checked the students' answer.

8) The researcher closed the class with giving assignment for homework.

\section{Data Analysis}

\section{a. Reading comprehension test}

1) Scoring the students' answers of pretest and posttest. Each of students' correct answer will get 1 and wrong answer will get 0 . The formula for indicating the students' score as follows:

\section{Obtained scores}

Score

$X 100$ (interval of the score level)

\section{Maximum scores}

(Depdiknas, 2017, p.38)

2) Classifying the scores of the students' answer. The scores were classified into seven level classifications which adapted to the scoring system from Depdiknas (2017, p.39) as follows: 


\begin{tabular}{ccc}
\hline No & $\begin{array}{c}\text { Interval } \\
\text { Score }\end{array}$ & Classification \\
\hline 1 & $96-100$ & Excellent \\
2 & $86-95$ & Very Good \\
3 & $76-85$ & Good \\
4 & $66-75$ & Fairly Good \\
5 & $56-65$ & Fair \\
6 & $36-55$ & Poor \\
7 & $0-35$ & Very Poor \\
\hline \multicolumn{4}{c}{ instrument item of Likert Scale } \\
sing the mean score of the & consisted of positive and negative
\end{tabular}

3) Calculating the mean score of the students' answer. To find out the mean score, standard deviation and the t-test value between the pre-test and the post-test of both experimental and control group by using Statistical Package for Social Sciences (SPSS) program version 20.0 (Gay et al, 2018:89).

\section{b. Questionnaire}

The data of questionnaire was analyzed by using Likert Scale. It is aimed to see the students' interest about the use of Prezi with KWL Strategy in enhancing reading comprehension. The measuring of

\section{Scoring Data}

The questionnaire was given to the students by using Likert scale. It aimed at asking the sample to respond to a series of statements by indicating whether one strongly agrees (SA), agrees (A), undecided (U), disagrees (D), or strongly disagrees (SD) with the statements given. Each response had its own value. Look at the table below:

Table 2. Likert Scale

\begin{tabular}{ccc}
\hline $\begin{array}{c}\text { Positive statement } \\
\text { Score }\end{array}$ & Category & $\begin{array}{c}\text { Negative } \\
\text { statement score }\end{array}$ \\
\hline 5 & Strongly Agree & 1 \\
4 & Agree & 2 \\
3 & Undecided & 3 \\
2 & Disagree & 4 \\
1 & Strongly Disagree & 5 \\
\hline
\end{tabular}

(Sugiyono,

2018, p.135)

2. Measuring the students'

As explained by the researcher previously, the questionnaire consisted of 20 items. It concern on four items namely: students' involvement, feeling of pleasure, attraction, and attention. Therefore, the students' interest can be classified as follow:

Table 3. Scoring Classification of the Students' Interest

\begin{tabular}{ccc}
\hline No. & $\begin{array}{c}\text { Interval } \\
\text { score }\end{array}$ & Classification \\
\hline 1 & $85-100$ & Very high \\
2 & $69-84$ & High \\
3 & $52-68$ & Moderate \\
\hline
\end{tabular}




\begin{tabular}{ccc}
\hline 4 & $36-51$ & Low \\
5 & $20-35$ & Very low \\
\hline
\end{tabular}

(Sugiyono, 2018, p.137)

RESULTS AND DISCUSSIONS

1 Students'

Comprehension

a. The Students Reading

Comprehension in Pre-test and

Post-test of Experimental and

Control Group

The distribution of the

score of the students' reading comprehension form experimental and control group in the post-test shows a difference from the pretest. After conducting the treatment, both group showed an improvement, but in the experimental group, improvement was higher than that of the control group. The rate percentage of pretest and posttest are shown in the table 4.

Table 4. The Rate Percentage of Pretest and Post-test

\begin{tabular}{|c|c|c|c|c|c|c|c|c|c|}
\hline \multirow{3}{*}{ Classification } & \multirow{3}{*}{ Score } & \multicolumn{4}{|c|}{ Experimental Group } & \multicolumn{4}{|c|}{ Control Group } \\
\hline & & \multicolumn{2}{|c|}{ Pretest } & \multicolumn{2}{|c|}{ Post test } & \multicolumn{2}{|c|}{ Pretest } & \multicolumn{2}{|c|}{ Post test } \\
\hline & & $\mathbf{F}$ & $\begin{array}{c}\mathbf{P} \\
(\%)\end{array}$ & $\mathbf{F}$ & $\begin{array}{c}\mathbf{P} \\
(\%)\end{array}$ & $\mathbf{F}$ & $\begin{array}{c}\mathbf{P} \\
(\%)\end{array}$ & $\mathbf{F}$ & $\begin{array}{c}\mathbf{P} \\
(\%)\end{array}$ \\
\hline Excellent & $96-100$ & 0 & 0 & 0 & 0 & 0 & 0 & 0 & 0 \\
\hline Very Good & $86-95$ & 0 & 0 & 19 & 53 & 0 & 0 & 1 & 3 \\
\hline Good & $78-85$ & 12 & 33 & 17 & 47 & 4 & 11 & 18 & 50 \\
\hline Fairly Good & $66-75$ & 15 & 42 & 0 & 0 & 15 & 42 & 16 & 44 \\
\hline Fair & $56-65$ & 7 & 19 & 0 & 0 & 13 & 36 & 1 & 3 \\
\hline Poor & $36-55$ & 2 & 6 & 0 & 0 & 4 & 11 & 0 & 0 \\
\hline Very Poor & $0-36$ & 0 & 0 & 0 & 0 & 0 & 0 & 0 & 0 \\
\hline Total & & 36 & 100 & 36 & 100 & 36 & 100 & 36 & 100 \\
\hline $\begin{array}{l}\text { Based or } \\
\text { he difference } \\
\text { xperimental gro } \\
\text { roup in pretest a }\end{array}$ & $\begin{array}{l}\text { the dat } \\
\text { frequen } \\
\text { p and } \\
\text { posttes }\end{array}$ & & & \multicolumn{6}{|c|}{$\begin{array}{l}\text { students percentage improv } \\
\text { significantly after treatment by usin } \\
\text { Prezi with KWL Strategy } \\
\text { experimental group than three phas } \\
\text { technique in control group. }\end{array}$} \\
\hline
\end{tabular}

Table 5. The Mean Score and experimental group in posttest 19 $(53 \%)$ students were classified as very good as classification while, in control class 1 (3\%) student was classified as very good as classification. It assumes that the

Standard Deviation of Students'

Reading

Comprehension in Pre-

test and Post-test 


\begin{tabular}{cccccc}
\hline \multirow{2}{*}{ No } & \multirow{2}{*}{ Group } & \multicolumn{2}{c}{ Mean Score } & \multicolumn{2}{c}{ Standard Deviation } \\
\cline { 3 - 6 } & & Pretest & Posttest & Pretest & Posttest \\
\hline 1 & Experimental & 69.69 & 86.61 & 8.655 & 5.228 \\
2 & Control & 66.22 & 75.89 & 7.491 & 6.480 \\
\hline
\end{tabular}

Table 5 explained that the mean score of pretest in experimental group was higher than control group, (69.69>66.22). 66.69 and 66.22 were classified as fairly good classification. This means that the students of the experimental and control groups were the same category before the treatment. Meanwhile, the mean score of posttest in the experimental group was higher than the mean score of the control group, (86.61>75.89). 86.61 was classified as very good category. While, 75.89 is classified as fairly good category. This means that Prezi with KWL Strategy which was applied in experimental group was more successful to enhance the students' reading comprehension than three phase technique which was applied in control group.

\section{Table 6. \\ The Probability Value of T-test of the Students' Reading \\ Comprehension Improvement in Experimental and the \\ Control Group}

\section{b. Test of significance (T-test)}

The hypotheses were tested by using inferential statistics. In this case, the researcher used t-test (testing of significance) for independent sample test. It was intended to know the significance difference between the result of the students' mean score in pretest and posttest in experimental group and control group. The result of t-test was calculated by using SPSS version 20.0. After using the statistics, the researcher found the probability value of t-test as presented in the following table 6 .

Independent Samples Test

\begin{tabular}{|c|c|c|c|c|c|c|c|c|c|}
\hline & \multicolumn{2}{|c|}{$\begin{array}{l}\text { Levene's Test } \\
\text { for Equality of } \\
\text { Variances }\end{array}$} & \multicolumn{7}{|c|}{ t-test for Equality of Means } \\
\hline & \multirow[t]{2}{*}{\begin{tabular}{l|l}
$\mathrm{F}$ &
\end{tabular}} & \multirow[t]{2}{*}{ Sig. } & \multirow[t]{2}{*}{$\mathrm{T}$} & \multirow[t]{2}{*}{ Df } & \multirow[t]{2}{*}{$\begin{array}{c}\text { Sig. } \\
(2- \\
\text { tailed })\end{array}$} & \multirow[t]{2}{*}{$\begin{array}{c}\text { Mean } \\
\text { Differe } \\
\text { nce }\end{array}$} & \multirow[t]{2}{*}{$\begin{array}{l}\text { Std. Error } \\
\text { Difference }\end{array}$} & \multicolumn{2}{|c|}{$\begin{array}{c}95 \% \\
\text { Confidence } \\
\text { Interval of the } \\
\text { Difference }\end{array}$} \\
\hline & & & & & & & & Lower & $\begin{array}{l}\text { Up } \\
\text { per }\end{array}$ \\
\hline $\begin{array}{l}\text { Equal variances } \\
\text { assumed }\end{array}$ & 457, & ,501 & 1,820 & 70 & ,073 & 3,47 & 1,90 &,- 33 & $\begin{array}{l}2 \\
7\end{array}$ \\
\hline
\end{tabular}




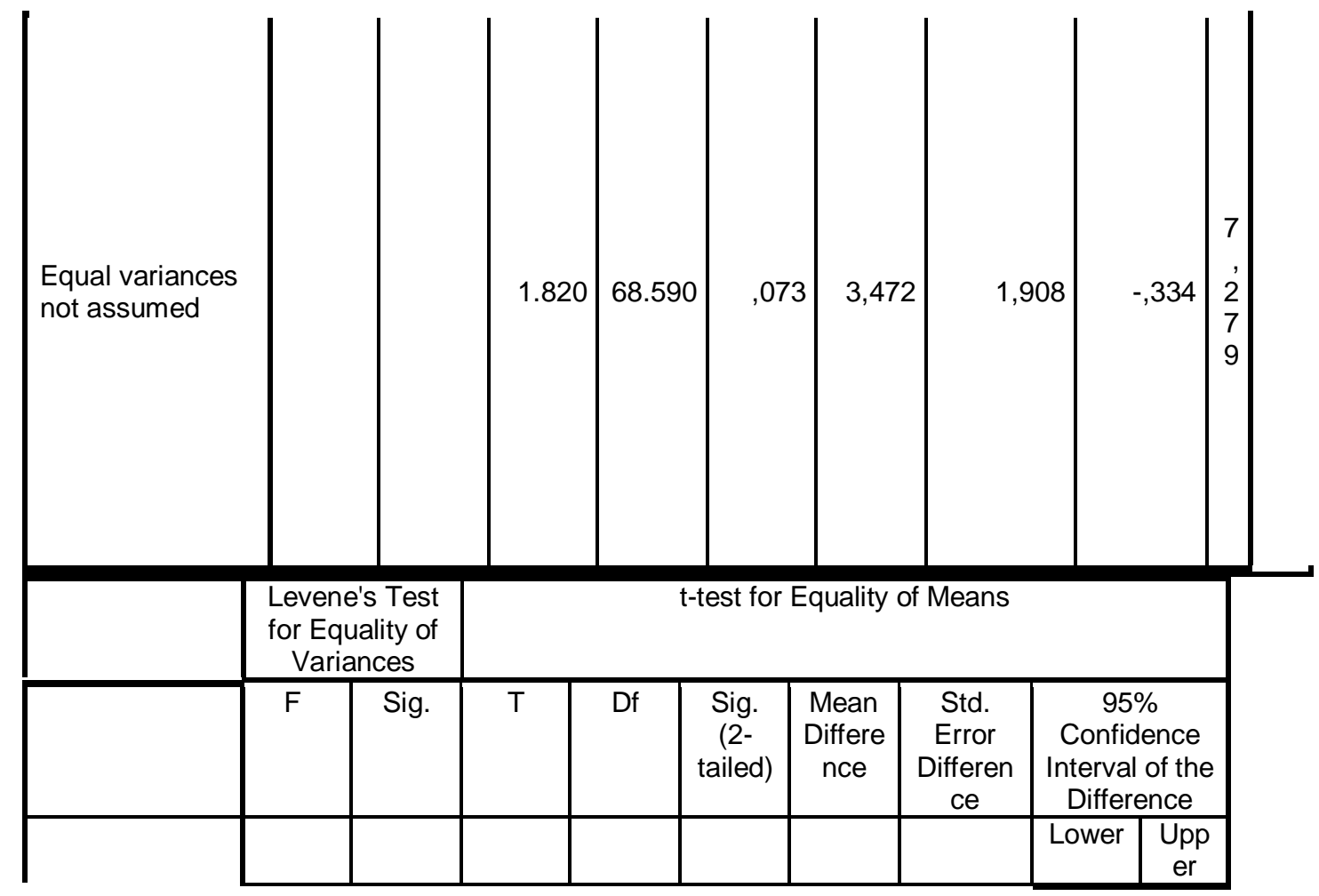

\begin{tabular}{|l|r|r|r|r|r|r|r|r|r|}
\hline $\begin{array}{l}\text { Equal variances } \\
\text { assumed }\end{array}$ & 2,719 &, 104 & 7,727 & 70 &, 000 & 10,722 & 1,388 & 7,955 & $\begin{array}{r}13, \\
490\end{array}$ \\
$\begin{array}{l}\text { Equal variances } \\
\text { not assumed }\end{array}$ & & 7,727 & 67,004 &, 000 & 10,722 & 1,388 & 7,953 & 492 \\
& & & & & & & & & \\
\end{tabular}

Based on the result of the data analysis as summarized in table 6 in the pretest of the experimental and the control groups, the researcher found that the probability value or $\mathrm{p}$ value (0.073) was higher than the level of significance $\alpha(0.05)$ or $0.073>0.05$. Whereas, the data in the posttest of the experimental group and control group shows that probability value (p-value) was smaller than $\alpha(0.000<0.05)$. It means that the alternative hypothesis (H1) is accepted while the null hypothesis is rejected. It assumed that there is significant difference between the students' reading comprehension improvement in the experimental group and the control group after the treatment.

\section{Students' Interest}

In accordance with the findings, it shown that the first grade students of SMA 2 Enrekang regency were interested in learning reading comprehension process by using Prezi and KWL Strategy. Most of the 
students' responses in the as experimental group were categorized

'interested'

Table 7. The Percentage of Students' Interest

\begin{tabular}{cclcc}
\hline No. & Interval & Categories & Frequency & $\begin{array}{c}\text { Percentage } \\
(\mathbf{\%})\end{array}$ \\
\hline 1 & $67-80$ & Very interested & 14 & 38.9 \\
2 & $54-66$ & Interested & 19 & 52.8 \\
3 & $42-53$ & Moderate & 3 & 8.3 \\
4 & $30-41$ & Uninterested & 0 & 0 \\
5 & $16-29$ & Very Uninterested & 0 & 0 \\
\hline \multicolumn{7}{c}{ Total } & $\mathbf{3 6}$ & $\mathbf{1 0 0}$ \\
\hline
\end{tabular}

According the data in the table 7 about the students' interest classification, the students had interest to learn English reading by using Prezi and KWL Strategy. It is proven by the mean score of the questionnaire which was 80.61 as classified into 'interested'. This also proven by the aggregate percentage of the students who got from questionnaire on item 1 up 20 about items. The result shown that 14 (38.9\%) students of 36 students were 'very interested', $19 \quad(52.8 \%)$ students of 36 students were 'interested', and $3(8.3 \%)$ students of 36 students were 'moderate'. from these findings, it can be inferred that most of the students have positive responds to the use of Prezi with KWL Strategy improving the students reading comprehension. In other word, the students are interested in reading narrative text by using Prezi with KWL Strategy. Furthermore, after analyzing between the result of the students' reading achievement and the students' interest in learning reading by using Prezi with KWL Strategy, it can be assumed that the use of Prezi with KWL Strategy is more applicable, effective and useful to increase the students' reading comprehension and the students' interest. It is proven by the mean score of experimental group in posttest which was 86.61 as categorized as very good classification, while the mean score of interest was 80.61 as categorized as interested classification.

\section{CONCLUSION AND SUGGESTION}

The use of Prezi with KWL Strategy was effective to enhance the students' reading comprehension. This is proven by the mean score posttest of the students' in the experimental group and control group which were difference. The mean score of the posttest in experimental group was higher than control group. It can be seen from the students' mean score of posttest was 86.61 for experimental group, while for control group the students' mean score of posttest was 75.89. 
Furthermore, the researcher found that all of the students' activities in using Prezi and KWL Strategy showed that the score of the students' in reading comprehension upgrade gradually.

The students' interest in experimental group was interest to learn English reading by using Prezi with KWL Strategy. it was proven by the mean score of the questionnaire was 80.61 categorized as interested classification. Therefore, the researcher found that all of the indicators of interest were reached which could be seen on the students' involvement, feelings of pleasure, attraction and attention.

Based on the conclusion above, the researcher would put some suggestion and recommendation. In teaching reading especially in teaching reading narrative .The researcher should share to the other researchers to use Prezi as teaching media in learning English. The teaching learning process should collaborate the Prezi and KWL Strategy to enhance students' reading comprehension. Related to the previous suggestion, the next researchers are suggested to explore more on blend of Prezi with another method, strategy, technique, or procedure that support teaching and learning process. Consequently, Prezi and KWL Strategy not only enhancing the students' interest and reading comprehension but also helping improve the student's creative skills, independence, and recognize of using sophisticated of technology in learning besides, using textbook as sources of learning.

\section{REFERENCES}

Baharuddin, E. Reading Approach Use, Effectiveness And EFL Reading Comprehension In University Muhammadiyah Of Parepare.

Depdiknas. (2017). Pembelajaran Bahasa Inggris. Jakarta: Badan Standar Nasional Pendidikan.

Elihami, E., \& Ismail, I. (2017). INCREASING STUDENTS'READING COMPREHENSION THROUGH COGNITIVE STRATEGIES OF SENIOR HIGH SCHOOL OF SIDENRENG RAPPANG REGENCY. EdumaspulJurnal Pendidikan, 1(2), 6170.

Gay, L.R., Millis, E., \& Airasian, P. (2018). Educational Research: Competencies for Analysis and Application. New Jersey. Prentise Hall.

Good.(2016. The Dictionary of Education. New York: McGraw-Hill Book Company.

Hamra, A., \& Syatriana, E. (2016). Developing a Model of Teaching Reading Comprehension for EFL Students. TEFLIN Journal. 21(1): 78-86 retrieved from www.journal.teflin.org/index. php/journal/.../33 September, $18^{\text {th }} 2016$ 
Harmer, J. (2017). The Practice of English Language Teaching. United States of America: Longman

Hawa, S. N. (2017). The Effect of Using Know Want Learn (KWL) Plus Strategy toward Reading Comprehension on Exposition Text of the Second Grade Students at Islamic Senior High School AlKautsar Pekanbaru. Teaching Traing Faculty of State Islamic University (UIN) Sultan Syarif Kasim Riau. Riau. Accessed on October, $21^{\text {st }} 2017$.

Jared, J., \& Elizabeth, J.H.A. (2017). Launching into Improved Comprehension. the Technology The researcher, 56(6), 90

Manning, C., Brooks, W., Crotteau, V., Diedrich, A., Moser, J., \& Zwiefelhofer. (2018). Tech Tools for The researchers by The researchers: Bridging The researcher and Students. Wisconcin English Journal. 53(1): 55 retrieved from www.

journals.library.wisc.edu/ind ex.php/wej/.../444. October, $21^{s t} 2018$

Ogle, D.M. (2018). Teaching Reading Model that Develop Active Reading the Heading The researcher. Evanston: Illinois.

Pintrich, R.E., Romeo,G.C., \& Muller, S.A.B. (2017).

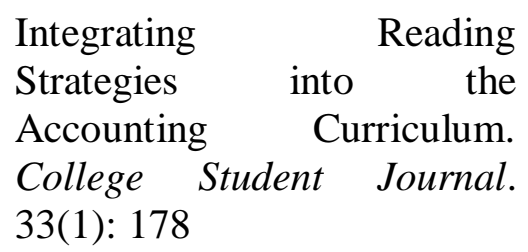

Riswanto., Risnawati., \& Lismayanti, D. (2017). The Effect of Using KWL (Know, Want, Learned) Strategy on EFL Students' Reading Comprehension

Achievement. International Journal of Humanities and Social Science. 4 (7) : 225231 retrieved from www.ijhssnet.com/journals/V ol 4.../28.pdf. October, $11^{\text {st }}$ 2017

Rivers, W. M. (2016). Teaching Reading Comprehension: An Interactive Pedagogie. New Jersey: San Fransisco State University.

Setiawan, A., Ikhsamuddin., \& Suhartono, L. (2018). The Effective of Teaching Reading Comprehension of Descriptive Text through KWL Strategy. The researcher Training Education Faculty of Tanjung University. Pontianak.

Strasser, N. (2016). Using Prezi In Higher Education. Journal of College Teaching \& Learning. 11 (2) : 90-95. Accessed on November, $4^{\text {th }} 2016$

Sugiyono. (2018). Metode Penelitian Pendekatan Kualitatif dan Kuantitatif, dan $R \& D$. Bandung: Alfabeta 
William, E. (2016). Reading in the Language Classroom. London. McMilan.

Zare, P., \& Othman, M. (2017). The Relationship beween Reading Comprehension and Reading Strategy Use among Malaysian ESL Learners. International Journal of Humanities and Social Science, 3 (13). Accessed on October, $9^{\text {th }}$ 2017 